\title{
Magnetic Resonance and Diffusion Weighted Imaging Findings of Head and Neck Paragangliomas
}

\section{Baş ve Boyun Paragangliomlarinin Manyetik Rezonans ve Difüzyon Ağırlıklı Görüntüleme Bulguları}

\author{
Altan Güneș ${ }^{1}$, Burce Ozgen ${ }^{2}$, Elif Bulut ${ }^{2}$, Nilda Süslü ${ }^{3}$, Anil Barak Dolgun ${ }^{4}$, Gaye Guler Tezel ${ }^{5}$, Kader Oguz $^{2}$ \\ ${ }^{1}$ Sağlık Bilimleri Üniversitesi, Ankara Çocuk Sağlığı ve Hastalıkları Hematoloji Onkoloji Eğitim Ve Araştırma \\ Hastanesi Radyoloji Kliniği \\ ${ }^{2}$ Hacettepe Üniversitesi Tıp Fakültesi, Radyoloji Anabilim Dalı \\ ${ }^{3}$ Hacettepe Üniversitesi Tıp Fakültesi, Kulak Burun Boğaz Anabilim Dalı \\ ${ }^{4}$ Hacettepe Üniversitesi Tıp Fakültesi, Biyoistatistik Anabilim Dalı \\ ${ }^{5}$ Hacettepe Üniversitesi Tıp Fakültesi, Patoloji Anabilim Dalı
}

Dergiye Ulaşma Tarihi: 31.03.2019 Dergiye Kabul Tarihi:18.06.2019 Doi: 10.5505/aot.2019.19971

\begin{abstract}
ÖZET
GİRiş ve AMAÇ: Baş ve boyun bölgesinde yerleşimli paragangliomlarının manyetik rezonans, difüzyon ağırlıklı görüntüleme bulgularını değerlendirmek ve görünür difüzyon katsayısı değerlerini karşılaştırmak.

YÖNTEM ve GEREÇLER: Çalışmamız hastane etik kurul onayı alınarak yapıldı. Ocak 2011 ile Ocak 2017 tarihleri arasında ardışık 39 hastanın (erkek/bayan=7/32; ortalama yaş \pm standar sapma $=52,9 \pm 13,8$ yıl, 19-79 yıl) klinik ve görüntüleme bulguları retrospektif değerlendirildi. Manyetik rezonans görüntüleri, tümörün lokalizasyonu, büyüklüğü, sinyal intensitesi ve homojenitesi, tuz-biber görünümünün varlığı, kontrastlanma derecesi, görünür difüzyon katsayısı değerleri bakımından değerlendirildi. Paragangliomlar, baş (glomus jugulare [13 hasta], timpanikum [2 hasta], jugulotimpanikum [11 hasta]) ve boyun (karotid cisim tümörleri [12 hasta], glomus vagale [1 hasta]) lezyonları olarak gruplandırıldı. Paragangliomların manyetik rezonans-difüzyon ağırlıklı görüntüleme bulguları gruplar arasında karşılaştırıldı. Görünür difüzyon katsayısı değerleri bakımından gözlemciler arası uyum, sınıf içi korelasyon katsayısı kullanılarak analiz edildi.

BULGULAR: Tuz-biber görünümünün izlendiği paragangliomların boyutları, bu görünümün izlenmediği paragangliomlardan daha büyüktü $(\mathrm{p}<0,001)$. Baş bölgesinde yerleşimli olan paragangliomların boyutları, boyun bölgesinde yerleşimli olanlara göre daha büyük, T2 sinyalleri daha düşük, difüzyon ağırlıklı görüntülemedeki sinyalleri ise daha yüksekti $(\mathrm{p} \leq 0,033)$. Paragangliomların ortalama görünür difüzyon katsayısı değeri $(0,89 \pm 0,50 \times 10-3 \mathrm{~mm} 2 / \mathrm{s})$, yerleşim yerlerine göre paragangliomlar arasında anlamlı farklılık göstermiyordu $(\mathrm{p}=0,127)$. Gözlemciler arası uyum iyi-mükemmeldi (sınıf içi korelasyon katsayısı $0,78-0,89$ ).

TARTIŞMA ve SONUÇ: Paragangliomların lokalizasyonları, boyutları, T2 ve difüzyon ağırlıklı görüntülerdeki sinyallerini, tuz-biber görünümü göstermelerini etkilemektedir. Konvansiyonel manyetik rezonans görüntüleme bulguları yanında görünür difüzyon katsayısı değerleri, paragangliomların diğer baş-boyun lezyonlarından ayırt edilmesinde yardımcı olabilir.
\end{abstract}

Anahtar Kelimeler: Paraganglioma, görünür difüzyon katsayısı değeri, tuz-biber görünümü

\begin{abstract}
INTRODUCTION: To evaluate magnetic resonance (MRI) and diffusion weighted imaging (DWI) characteristics of head and neck paragangliomas and to compare the apparent diffusion coefficient values (ADCV) of the paragangliomas.

METHODS: The study was approved by the local ethics committee. We retrospectively reviewed the medical and imaging records of 39 consecutive patients $($ male/female $=7 / 32$; mean age $=52.9 \pm 13.8$ years, range 19-79 years) with paragangliomas between January 2011 and January 2017. All MRI were evaluated for tumor location, size, signal intensity and homogeneity, the presence of salt and pepper (S\&P) appearance, contrast enhancement degree, and the ADCV. The paragangliomas were grouped as neck (carotid body tumor $[\mathrm{n}=12]$ and glomus vagale $[n=1]$ ) and head (glomus jugulare [n=13], tympanicum $[n=2]$, and jugulotympanicum [n=11]) lesions and MRI features were also compared between these groups. Inter-observer agreements for ADCVs were estimated by using the intraclass correlation coefficient.
\end{abstract}

RESULTS: The paragangliomas showing S\&P appearance had larger diameters than those did not $(\mathrm{p}<0.001)$. The paragangliomas located in the head had larger diameters and lower T2 signal intensity than those located in 
the neck ( $\mathrm{p} \leq 0.023$ ). DWI signal intensity of tumors located in the neck were lower than those located in the head $(\mathrm{p}=0.033)$. The mean ADCV of all paragangliomas was $0.89 \pm 0.50 \times 10-3 \mathrm{~mm} 2 / \mathrm{s}$, with no significant differences identified among the paragangliomas $(\mathrm{p}=0.127)$. Inter-observer reliability was found to be substantial to excellent (intraclass correlation coefficient range, $0.78-0.89$ ).

DISCUSSION and CONCLUSION: The localization and sizes of paragangliomas affect the presence of S\&P apperance, DWI and T2 signal intensity. The addition of ADCV of paragangliomas to conventional MRI findings may increase the accuracy of imaging in distinguishing other head and neck lesions.

Keywords: Paraganglioma, apparent diffusion coefficient, salt and pepper appearance

\section{INTRODUCTION}

Paragangliomas of the head and neck (H\&N) are noncapsulated, hypervascular, slowly growing tumors of neural crest origin $(1,2)$. They may be classified as hereditary and nonhereditary, and the hereditary forms tend to be multicentric and bilateral, with an earlier onset of symptoms (3). Despite their benign histopathological features, paragangliomas behave as locally aggressive neoplasms and may occasionally manifest a malignant course with local nodal or distant metastases (4). Unlike several neck lesions, biopsy is not preferred for the diagnosis of paragangliomas because of their tendency to bleed. The diagnosis of paragangliomas is usually based on clinical and imaging findings. Although digital subtraction angiography was considered as the primary diagnostic modality for paragangliomas previously, nowadays computed tomography (CT) and magnetic resonance imaging (MRI) have become the preferred modalities for diagnosis (5-7).

The aims of this study were to evaluate conventional MR and diffusion weighted imaging (DWI) characteristics of paragangliomas of the $\mathrm{H} \& \mathrm{~N}$ and to compare the apparent diffusion coefficient (ADC) values of the paragangliomas with tumors in the differential diagnosis of paragangliomas.

\section{MATERIALS and METHODS}

\section{Patients}

The study was approved by the local ethics committee (ethics reference number: 16969557-717). This retrospective study included 39 consecutive patients (male/female $=7 / 32$, ratio $1: 4.6$, mean age $=52.9 \pm 13.8$ years, range, 19-79 years) who were referred with the diagnosis or suspicion of paraganglioma from the Department of Otorhinolaryngology, between January 1, 2006, and January 1, 2017. The patients having clinical\&radiological diagnosis of paragangliomas and having nasopharynx/neck MRI studies with DWI were included in the study. The exclusion criteria were as follows: missing clinical data $(n=2)$, irregular followup of patients $(\mathrm{n}=3)$ and tecniqually inadequate MRIs due to motion artifacts $(\mathrm{n}=$ 3). Medical records were reviewed to determine patients' clinical history, presentation, and outcome by an otorhinolaryngologist (N.S., with 14 years of experience in otorhinolaryngology).

\section{Magnetic resonance imaging technique}

All MR imaging were performed on a $1.5 \mathrm{~T}$ scanners (Symphony [24 patients], Siemens, Germany; Achieva [7 patients], Philips Healthcare, the Netherlands, or GE [8 patients] Healthcare, WI) with head and neck coil. The imaging technique included spin-echo (SE) T1-weighted imaging (WI) (repetition time $(\mathrm{TR}) /$ echo time $(\mathrm{TE})=550-600 / 12-15 \mathrm{~ms})$ in 3 planes, axial and coronal turbo SE T2WI $(\mathrm{TR} / \mathrm{TE}=4000-4200 / 70-80 \mathrm{~ms})$, postgadolinium (intravenous $0.1 \mathrm{mmol} / \mathrm{kg}$ ) $\mathrm{SE}$ axial and coronal T1WI (TR/TE $=400$ 620/14-20 ms) or 3D T1 magnetizationprepared rapid gradient-echo $(\mathrm{TR} / \mathrm{TE}=$ $897 / 4.55 \mathrm{~ms}$, inversion time $=600 \mathrm{~ms})$, and single-shot echo-planar DWI (applied with $3 \mathrm{~b}$ values with a maximum of $1000 \mathrm{~s} / \mathrm{mm}^{2}$, TR/TE $=4000-5000 / 60-70 \mathrm{~ms}$ ). All studies were performed with 3-mm section thickness and fat suppression on $\mathrm{T} 2 \mathrm{~W}$ and post-gadolinium images.

\section{Image evaluation}

All MRI studies were evaluated with respect to tumor location, size (long- and short-axis diameters measured on the postcontrast T1WI, signal intensity (compared to muscle) and texture, the presence of flow voids (salt and pepper $[\mathrm{S} \& \mathrm{P}]$ appearance, salt refers to high signal foci of hemorrhage and/or slow flow on 
T1WI, and pepper refers to the low signal due to high flow), degree of contrast enhancement (none, mild, moderate, and marked), diffusion characteristics (compared to brain parenchyma), and ADC values by 1 neuroradiologist (A.G.). Tumor enhancement similar to muscle was considered as moderate, those less than muscle was considered as poor, and the enhancement approaching the vessels was considered as marked. The paragangliomas were grouped as neck (carotid body tumor and glomus vagale) and head (glomus jugulare, tympanicum, and jugulotympanicum) lesions and MRI features were also compared between these groups.

Freehand region of interest (ROI) measurements were performed on the ADC maps and ROIs were drawn on the darkest area of the tumor with the guidance of $\mathrm{T} 1$ - and T2WI to identify the most cellular areas. ADC measurement was also obtained from the pons with the same-size ROIs as an internal quality check to assess the validity of our measurements. Three separate measurements with similar ROI size were made from each tumor, and then the mean ADC for tumors and the ADC tumor/pons ratios were calculated. To establish the reproducibility and the reliability of the ADC values, the inter-observer variability was assessed by 2 observers (A.G. and B.M., with 8 and 12 years of experience in H\&N imaging, respectively) for 20 patients who were selected at random. The measurements of the ADC values were performed using the software available on workstations provided by the corresponding manufacturer (Leonardo workstations, Siemens; View Forum workstations, Philips Healthcare; Infinity workstations, GE Healthcare).

\section{Statistical analysis}

The numerical variables were expressed as mean \pm standard deviation, or median (interquartile range [IQR]), and a comparative analysis of these variables was performed using $t$, Mann-Whitney $\mathrm{U}$, or Kruskal-Wallis tests. The categorical variables were expressed as number and percentage. The $\chi^{2}$ or Fisher's exact test was used for a comparative analysis of the categorical variables. The inter-observer agreement was estimated using the intraclass correlation coefficient (ICC, range $=-1$ to +1 ), which was interpreted as follows: $<0.40$, poorto-fair agreement; $0.41-0.60$, moderate agreement; 0.61-0.80, substantial agreement; and 0.81-1.00, almost perfect agreement. Bland-Altman plots were used to demonstrate the relationship between the results of 2 observers. Statistical analysis was conducted with statistical software (SPSS, version 21.0; SPSS Inc, Chicago, IL, USA). Results were considered statistically significant at $\mathrm{p}<0.05$.

\section{RESULTS}

There were 13 glomus jugulare, 11 jugulotympanicum, 2 tympanicum, 1 vagale, and 12 carotid body tumors. No significant difference was found between ages of the males ( $45.1 \pm 19$ years) and females $(54.6 \pm 12$ years $)(p=0.100)$. The most common symptoms were painless neck mass (10/39, $25.6 \%)$, pain $(3 / 39,7.7 \%)$, pulsatile tinnitus $(10 / 39,25.6 \%)$, and vertigo $(6 / 39,15.3 \%)$.

The paragangliomas located in the head had larger long- and short-axis diameters than those located in the neck $(p=0.003, p=$ 0.001 , respectively). The $\mathrm{S} \& \mathrm{P}$ appearances were seen in $76.9 \%(30 / 39)$ of tumors and those showing the S\&P appearance had larger long- and short-axis diameters than those did not $(\mathrm{p}<0.001)$ (Figure 1a). No significant difference was found in S\&P appearance between the paragangliomas located in the neck and those located in the head $(p=1)$. No significant difference was found in $\mathrm{T} 1$ and $\mathrm{T} 2$ signal intensity among the paragangliomas ( $\mathrm{p}=$ $0.404, \mathrm{p}=0.051$, respectively). The tumors located in the head had lower T2 signal intensity than those located in the neck $(\mathrm{p}=$ 0.023). All paragangliomas had a heterogeneous texture on T2WI and showed marked contrast enhancement (Figure 1b). The signal intensity of tumors located in the neck were lower than those located in the head on DWI ( $p=0.033$ ) (Figure 1c). Regardless of the localization, the mean ADC value $(0.89 \pm 0.50$ $\times 10^{-3} \mathrm{~mm}^{2} / \mathrm{s}$ ) of the paragangliomas and ADC lesion:pons ratio $(1.54 \pm 0.44)$ show no significant differences among the paragangliomas $(\mathrm{p}=0.127, \mathrm{p}=0.572$, respectively), and between the paragangliomas located in the neck and those located in the head ( $p=0.061, p=0.475$, respectively) (Figure 1d). The mean ADC value of pons was $0.58 \pm 0.29 \times 10^{-3} \mathrm{~mm}^{2} / \mathrm{s}$, with no significant 
difference identified between the scanners $(\mathrm{p}=$ 0.704) (Figure 1e). Inter-observer reliability was found to be substantial (ADC values of paragangliomas $[\mathrm{ICC}=0.78]$ ) to excellent (ADC values of pons [ICC $=0.89]$, ADC lesion:pons ratios [ICC $=0.81])(\mathrm{p}<0.001)$ (Figure 2). The details of the imaging findings were presented in Tables 1, 2.

Of the 33 paragangliomas, 15 were treated with radiotherapy and 12 were treated with surgery. Endovascular embolization was used preoperatively in 3 patients (carotid body tumors $[\mathrm{n}=2]$, glomus vagale $[\mathrm{n}=1]$ ) and prior to radiotherapy in 2 patients (glomus jugulare $[\mathrm{n}=1]$ and jugulotympanicum $[\mathrm{n}=$ 1]). Neither radiotherapy nor surgical treatment was performed in 6 patients as they were managed conservatively by monitoring. A histological diagnosis was available for 12 patients (carotid body tumors $[n=8]$, glomus jugulare $[n=1]$ and jugulotympanicum $[n=$ $3]$ ). The mean clinical follow-up was 4.4 years (range, 1-10 years).

\section{DISCUSSION}

Paragangliomas may arise in various locations of the $\mathrm{H} \& \mathrm{~N}$; however, they are most commonly observed in the carotid bifurcation and the jugular fossa, as found in our study (8). Typically, paragangliomas manifest between the third and sixth decades of life, with a marked female predominance, and the majority of patients have a painless mass or a pulsatile tinnitus at presentation $(2,3,9)$. Our results were in agreement with these findings. All our cases were sporadic and no multifocal or metastatic lesions were found (4).

van den Berg $\mathrm{R}$ et al. have reported that the combination of imaging features with the typical localization and vessel displacements, enlarged feeding vessels, and intratumoral flow-related signal helps in the diagnosis of paragangliomas (10). The conventional MRI findings for the paragangliomas include low- to-intermediate signal and the S\&P appearance on T1WI, hyperintense signal on T2WI, and marked contrast enhancement, as observed in our study (11). The displacement and relative position of the carotid arteries could be used as an efficient tool for differential diagnosis of paragangliomas. Besides paragangliomas, schwannoma of the cervical sympathetic chain may cause displacement of the internal and common carotid arteries in an anterior and lateral direction (12). Although they could occur at similar locations, the carotid body tumors tend to separate the internal and external carotid arteries by filling the crotch of the bifurcation, whereas glomus vagale displace the carotid arteries anteriorly and the internal jugular vein posteriorly due to the course of the $10^{\text {th }}$ nerve $(13-15)$. In our study, all paragangliomas located in the neck, except one glomus vagale, filled the crotch of the bifurcation. The small size of glomus vagale presumably did not cause mass effect on these vessels in our study.

The imaging appearance reflects the hypervascular nature and the flow characteristics of the paragangliomas, resulting in enlarged feeding vessels, S\&P appearance, high relative cerebral blood volume, and early contrast uptake on dynamic CT and MR angiography. These findings besides the S\&P appearance can be assessed by different MR angiography techniques (i.e., contrastenhanced 3D time-of-flight, 4D time-resolved angiography with keyhole) and perfusion MR imaging $(6,7,16)$. The S\&P appearance, which is a variable finding in the paragangliomas, was not detected in $23 \%$ of the tumors in our study. It has been reported that this appearance is especially observed in larger paragangliomas, and it may also be found in schwannoma, other vascular tumors, and metastatic lesions $(5,16)$. In our study, the average long- $(2.6 \mathrm{~cm})$ and short-axis $(1.9 \mathrm{~cm})$ diameters of the paragangliomas that showing the S\&P appearance was higher than those did not, similar to the previous report by van den Berg R et al (10). This result shows that the $\mathrm{S} \& \mathrm{P}$ appearance is not a reliable finding alone for detecting paragangliomas.

In our study, there was variability in ADC values within $H \& N$ paragangliomas. The mean ADC value of the paragangliomas located in the neck was higher than those located in the head, the difference did not reach a significant level. The reason for this finding may be that the paragangliomas located in the neck were larger in size compared to those located in the head. The increased tumor vasculature associated with the increased tumor size may affect the ADC values of paragangliomas due to incoherent motion (17, 18). In the literature, there is a little 
information available regarding DWI and ADC values of paragangliomas (19). Ying Yuan et al. reported the mean ADC value of the 10 paragangliomas, which had mainly involved the carotid body tumors, was $1.12 \pm 0.15 \times 10^{-3}$ $\mathrm{mm}^{2} / \mathrm{s}$ and this value was lower than our result $\left(1.31 \times 10^{-3} \mathrm{~mm}^{2} / \mathrm{s}\right)(19)$.

DWI has gained increasing importance in the differentiation of benign and malignant H\&N lesions $(20,21)$. There have been several studies investigating the ability of ADC values to differentiate between benign and malignant $\mathrm{H} \& \mathrm{~N}$ lesions. Wang et al. (21) demonstrated that ADC threshold value of $1.22 \times 10^{-3} \mathrm{~mm}^{2} / \mathrm{s}$ may be helped to distinguish benign from malignant tumors in the $\mathrm{H} \& \mathrm{~N}$ region. This threshold value was reported as $1.25 \times 10^{-3}$ $\mathrm{mm}^{2} / \mathrm{s}$ by Abdel Razek AA et al (22). Regardless of the localization, the mean ADC value of the all paragangliomas $(0.89 \pm 0.50 \times$ $10^{-3} \mathrm{~mm}^{2} / \mathrm{s}$ ) and the paragangliomas located in the head $\left(0.93 \times 10^{-3} \mathrm{~mm}^{2} / \mathrm{s}\right)$ were lower than the previous studies $(21,22)$. Our results show that although DWI shows the potential in characterizing and differentiating head and neck lesions, there are also exceptions and overlaps.

Our study has some limitations as follows: a) its retrospective nature, b) the follow-up period of 3 patients was less than one year and these patients are still in followup at the time of reporting the study, c) we did not analyze the MR angiography of all patients because some of the patients were evaluated with CT angiography. Also, the majority of patients did not have any perfusion MR studies.

In conclusion, the localization and sizes of paragangliomas affect the presence of salt and pepper appearance, DW trace and T2 signal intensity. The addition of ADC values of paragangliomas to conventional MRI findings may increase the accuracy of imaging in distinguishing other $\mathrm{H} \& \mathrm{~N}$ lesions.

\section{Conflict of interest: None}

Table 1: The table showed demographic and imaging findings of the patients with paragangliomas.

\begin{tabular}{|c|c|c|c|c|c|c|}
\hline & $\begin{array}{c}\text { CBT } \\
(n=12)\end{array}$ & $\begin{array}{c}G V \\
(n=1)\end{array}$ & $\begin{array}{c}\text { GJJ } \\
(n=13)\end{array}$ & $\begin{array}{c}\text { GT } \\
(n=2)\end{array}$ & $\begin{array}{c}\text { G.JT } \\
(n=11)\end{array}$ & $\begin{array}{c}\text { Total } \\
(n=39)\end{array}$ \\
\hline $\operatorname{Sex}(M / F), n$ & $3 / 9$ & $\mathrm{O} / 1$ & $3 / 10$ & $\mathrm{O} / 2$ & $1 / 10$ & $7 / 32$ \\
\hline Long-AD, mm & 28 & 12 & 20 & 19.5 & 22 & $25.6 \pm 11.6 *$ \\
\hline (median, IQR) & $21.5-30$ & & $17-29$ & $13-26$ & $17-32$ & $12-69$ \\
\hline \multirow[t]{2}{*}{ Short-AD, mm } & 21.5 & & 17 & 14.5 & 18 & $21.3 \pm 11.7 *$ \\
\hline & $16.5-27$ & & $14-21.5$ & $11-18$ & $14-26$ & $10-67$ \\
\hline S\&P appearance, $n$ & 10 & o & 10 & o & 10 & 30 \\
\hline \multicolumn{7}{|l|}{ T1 SI, n } \\
\hline low-isointense & 12 & 1 & 10 & 2 & 9 & 34 \\
\hline hyperintense & - & - & 3 & - & 2 & 5 \\
\hline \multicolumn{7}{|l|}{ T2 SI, n } \\
\hline mild hyperintense & 2 & 1 & 8 & 1 & 7 & 19 \\
\hline moderate hyperintense & 10 & - & 5 & 1 & 4 & 20 \\
\hline \multicolumn{7}{|l|}{ DW trace SI, n } \\
\hline similar to $B P$ & 4 & 1 & 9 & 2 & 9 & 25 \\
\hline higher than $B P$ & 8 & - & 4 & - & 2 & 14 \\
\hline ADC lesion $\left(\times 10^{-3} \mathrm{~mm}^{2} / \mathrm{s}\right)$ & 1.20 & 1.31 & 0.80 & 0.15 & 0.98 & $0.89 \pm 0.50 *$ \\
\hline (median, IQR) & $0.73-1.45$ & & $0.15-1.22$ & $0.10-0.19$ & $0.67-1.29$ & $0.86-1.66$ \\
\hline ADC lesion:pons ratio & 1.58 & 2.08 & 1.57 & 1.70 & 1.54 & 1.57 \\
\hline (median, IQR) & $1.22-1.84$ & & $1.14-1.85$ & $1.40-2.01$ & $1.33-1.62$ & $1.28-1.84$ \\
\hline
\end{tabular}

M: male, F: female, CBT: carotid body tumors, GV: glomus vagale, GJ: glomus jugulare, GT: glomus tympanicum, GJT: glomus jugulotympanicum, AD: axis diameters, mm: millimeter, S\&P: salt and pepper appearance, SI: signal intensity, DW: diffusion weighted, BP: brain parenchyma, ADC: apparent diffusion coefficient, IQR: interquartile range, *: mean \pm standard deviation, ranges. 
Table 2: The table showed the imaging findings and statistical analysis of paragangliomas.

\begin{tabular}{|c|c|c|c|}
\hline & $\begin{array}{c}\text { Paragangliomas } \\
\text { located in the } \\
\text { head }(n=26)\end{array}$ & $\begin{array}{l}\text { Paragangliomas } \\
\text { located in the } \\
\text { neck }(n=13)\end{array}$ & $\mathbf{p}$ \\
\hline $\begin{array}{l}\text { Long-AD, mm } \\
\text { (median, IQR) }\end{array}$ & $\begin{array}{c}20 \\
(16.7-24)\end{array}$ & $\begin{array}{c}30 \\
(27.5-39)\end{array}$ & 0.003 \\
\hline Short-AD, mm & $\begin{array}{c}16 \\
(14-18)\end{array}$ & $\begin{array}{c}27 \\
(19.5-29)\end{array}$ & 0.001 \\
\hline S\&P appearance, $n$ & 20 & 10 & 1 \\
\hline $\begin{array}{l}\text { T1 SI, n } \\
\text { low-isointense } \\
\text { hyperintense }\end{array}$ & $\begin{array}{c}21 \\
5\end{array}$ & $\begin{array}{r}13 \\
-\end{array}$ & 0.404 \\
\hline $\begin{array}{l}\text { T2 SI, } \mathbf{n} \\
\text { mild hyperintense } \\
\text { moderate hyperintense }\end{array}$ & $\begin{array}{l}16 \\
10\end{array}$ & $\begin{array}{c}3 \\
10\end{array}$ & 0.023 \\
\hline $\begin{array}{l}\text { DW trace } \mathbf{S I}, \mathbf{n} \\
\text { similar to } B P \\
\text { higher than } B P\end{array}$ & $\begin{array}{c}20 \\
6\end{array}$ & $\begin{array}{l}5 \\
8\end{array}$ & 0.033 \\
\hline $\begin{array}{l}\text { ADC lesion, }\left(\times 10^{-3} \mathrm{~mm}^{2} / \mathrm{s}\right) \\
\text { (median, IQR) }\end{array}$ & $\begin{array}{c}0.93 \\
0.19-1.24\end{array}$ & $\begin{array}{c}1.31 \\
0.81-1.43\end{array}$ & 0.061 \\
\hline $\begin{array}{l}\text { ADC lesion:pons ratio } \\
\text { (median, IQR) }\end{array}$ & $\begin{array}{c}1.55 \\
1.26-1.83\end{array}$ & $\begin{array}{c}1.59 \\
1.29-1.95\end{array}$ & 0.475 \\
\hline
\end{tabular}

S\&P: salt and pepper appearance, SI: signal intensity, AD: axis diameters, mm: millimeter, IQR: interquartile range, DW: diffusion weighted, BP: brain parenchyma, ADC: apparent diffusion coefficient.

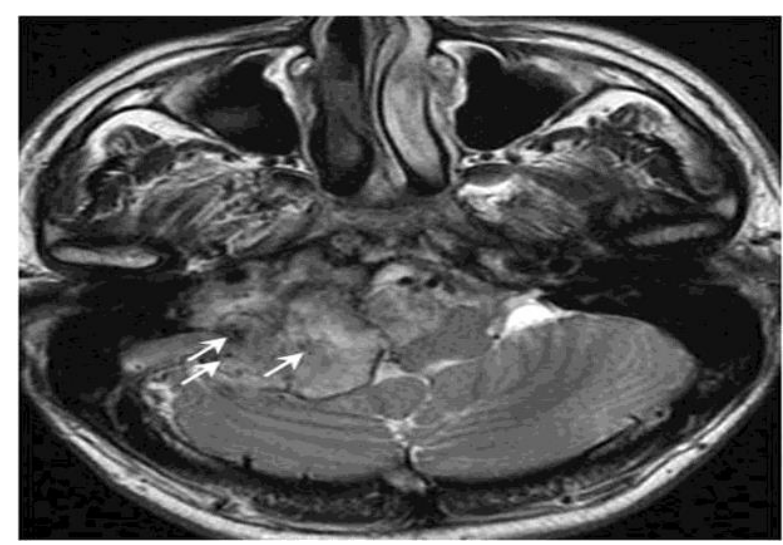

Figure 1a: 63-year-old man with right-sided glomus jugulare. Axial fat-suppressed turbo spin-echo T2-weighted image shows punctuate areas of low signal consistent with flow voids (arrow) within a large soft tissue mass extending to the cerebellopo

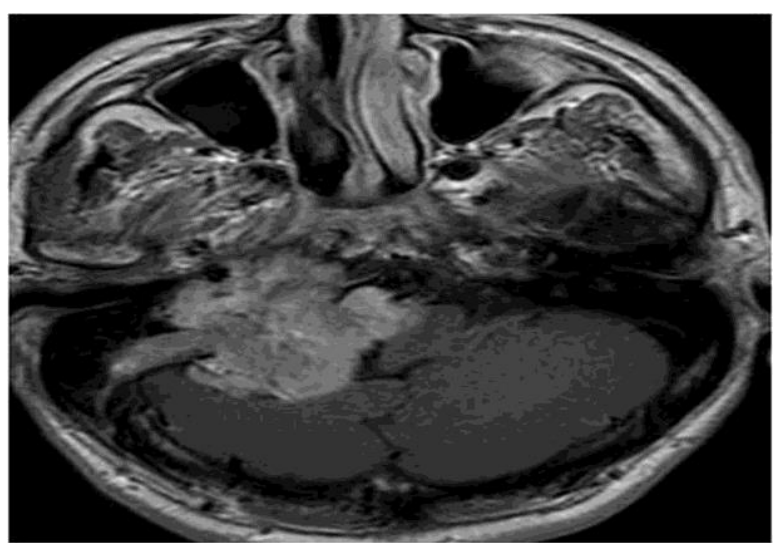

Figure 1b: The post-contrast T1-weighted image shows marked contrast enhancement of glomus jugulare 


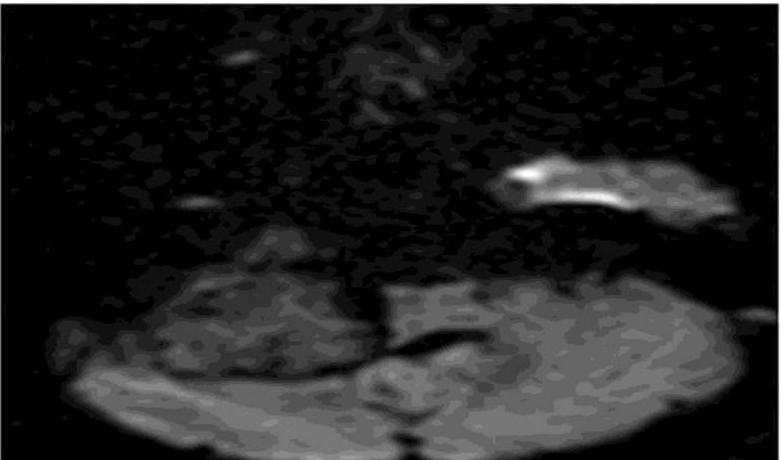

Figure 1c: The glomus jugulare shows similar or lower signal than brain parenchyma on diffusion weighted imaging

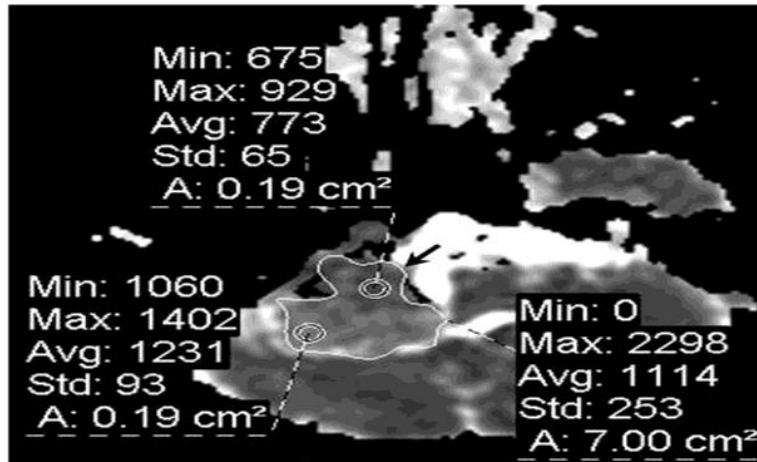

Figure 1d: Apparent diffusion coefficient (ADC) map image demonstrates the freehand region of interest (ROI) measurements. The ROI is placed in the darkest portion of the glomus jugulare on the ADC map (arrow, $0.7 \times 10^{-3} \mathrm{~mm} 2 \mathrm{~s}$ ).

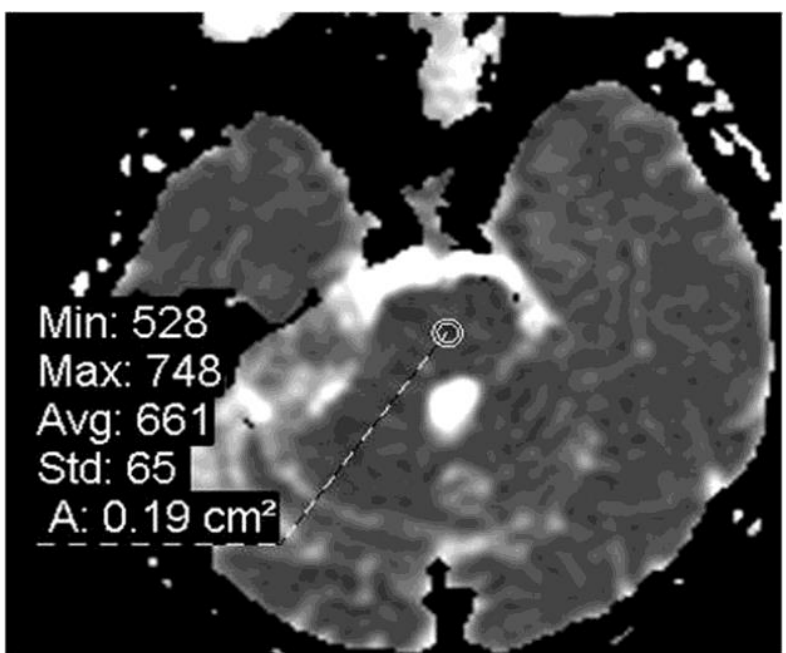

Figure 1e: ADC map image shows the ROI measurement of pons

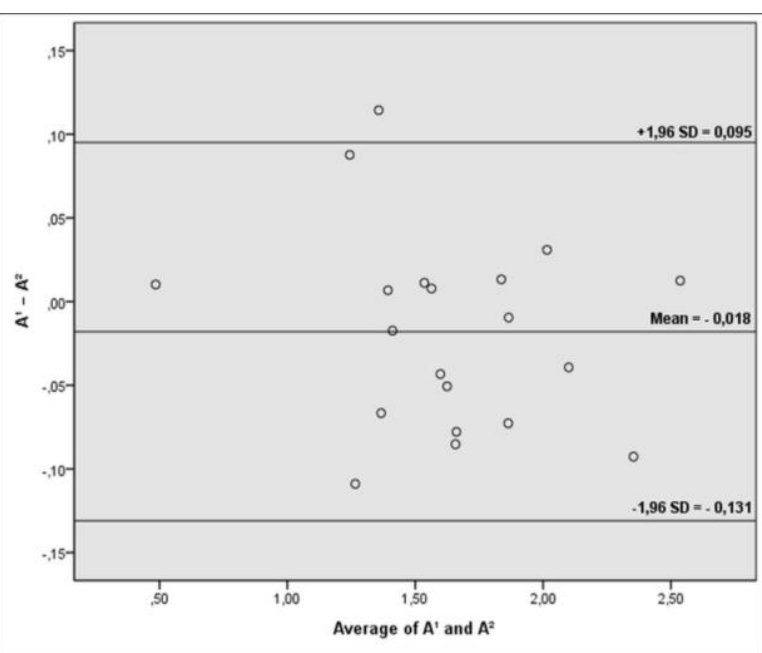

Figure 2: Bland-Altman plot shows interobserver variability for ADC lesion: pons ratios. The 95 confidence limits of agreement are between 0.8722;0.131 and 0.095.

\section{REFERENCES}

1. Murphy TE, Huvos AG, Frazell EL. Chemodectomas of the glomus intravagale: vagal body tumors, nonchromaffin paragangliomas of the nodose ganglion of the vagus nerve. Ann Surg. 1970;172:246-5.

2. Mafee MF, Raofi B, Kumar A, Muscato C. Glomus faciale, glomus jugulare, glomus tympanicum, glomus vagale, carotid body tumors, and simulating lesions: role of MR imaging. Radiol Clin N Am. 2000;38:1059-76.

3. van der Mey AG, Jansen JC, van Baalen JM. Management of carotid body tumors. Otolaryngol Clin North Am. 2001;34:907-24.

4. da Silva AD, O'Donnell S, Gillespie D, Goff J, Shriver C, Rich N. Malignant carotid body tumor: a case report. J. Vasc Surg. 2000;32:821-3.

5. van den Berg R. Imaging and management of head and neck paragangliomas. Eur Radiol. 2005;15:1310-18.

Adress for correspondence: Uzm. Dr. Altan Güneș, Dışkapı Ankara - Türkiye -mail: draltangunes@gmail.com

Available at www.actaoncologicaturcica.com

Copyright $\odot$ Ankara Onkoloji Hastanesi
6. van den Berg R, Schepers A, de Bruine FT, et al. The value of MR angiography techniques in the detection of head and neck paragangliomas. Eur J Radiol. 2004;52:240-5.

7. Bonneville F, Savatovsky J, Chiras J. Imaging of cerebellopontine angle lesions: an update. Part 1: enhancing extra-axial lesions. Eur Radiol. 2007;17:2472-82.

8. Garcia MAS, Pendàs JLL, Tapia JPR, et al. Head and Neck Paragangliomas: Revision of 89 cases in 73 patients. Acta Otorinolaringol Esp. 2007;58:94100.

9. Jackson CG. Glomus tympanicum and glomus jugulare tumors. Otolaryngol Clin North Am. 2001;34:941-70.

10. van den Berg R, Verbist BM, Mertens BJA, van der Mey AGL, van Buchem MA. Head and neck paragangliomas: improved tumor detection using contrast-enhanced 3D time-off light MR angiography as compared with fat-suppressed MR imaging techniques. Am J Neuroradiol. 2004;25:863-70. 
11. Olsen WL, Dillon WP, Kelly WM, Norman D, Brant-Zawadzki M, Newton TH. MR imaging of paragangliomas. Am J Roentgenol. 1987;148:2014.

12. Harnsberger HR, Osborn AG. Differential diagnosis of head and neck lesions based on their space of origin. 1. The suprahyoid part of the neck. AJR Am J Roentgenol. 1991;157:147-54.

13. Anil G, Tan TY. Imaging characteristics of schwannoma of the cervical sympathetic chain: a review of 12 cases. AJNR Am J Neuroradiol. 2010;31:1408-12.

14. Som PM, Curtin HD. Parapharyngeal space. In: Som PM, Curtin HD, eds. Head and Neck Imaging (3rd ed). St Louis;Mosby;1996:915-51.

15. Arya S, Rao V, Juvekar S, Dcruz AK. Carotid body tumors: objective criteria to predict the Shamblin group on MR imaging. AJNR Am J Neuroradiol. 2008;29:1349-54.

16. Som PM, Braun IF, Shapiro MD, Reede DL, Curtin $\mathrm{H}$, Zimmerman R. Tumors of the parapharyngeal space and upper neck: MR imaging characteristics. Radiology. 1987;164:823-9.

17. Le Bihan D, Breton E, Lallemand D, Crenier P, Cabanis E, Laval-Jeantet M. MR imaging of intravoxel incoherent motions: application to diffusion and perfusion in neurologic disorders. Radiology. 1986;161:401-7.

18. Le Bihan D, Breton E, Lallemand D, Aubin ML, Vignaud J, Laval-Jeantet M. Separation of diffusion and perfusion in intravoxel incoherent motion MR imaging. Radiology. 1988;168:497-505.

19. Yuan $Y$, Shi $H$, Tao $X$. Head and neck paragangliomas: diffusion weighted and dynamic contrast enhanced magnetic resonance imaging characteristics. BMC Med Imaging. 2016;16:12.

20. Surov A, Ginat DT, Sanverdi E, et al. Use of diffusion weighted imaging in differentiating between malignant and benign meningiomas. A multicenter analysis World Neurosurg. 2016;88:598-602.

21. Wang J, Takashima S, Takayama F, et al. Head and Neck Lesions: Characterization with Diffusionweighted Echo-planar MR Imaging. Radiology. 2001;220:621-30.

22. Abdel Razek AA, Gaballa G, Elhawarey G, Megahed AS, Hafez M, Nada N. Characterization of pediatric head and neck masses with diffusionweighted MR imaging. Eur Radiol. 2009;19:201-8. 